\title{
Karyotype of Brachanthemum krylovii Serg.
}

\author{
Sergey V. Smirnov ${ }^{1}$ and Katsuhiko Kondo ${ }^{2}$ \\ ${ }^{1}$ Department of Systematic Botany, Faculty of Biology, Altai State University, \\ Barnaul 656099, Russia; ${ }^{2}$ Laboratory of Plant Genetics and Breeding \\ Science, Department of Agriculture, Faculty of Agriculture, Tokyo \\ University of Agriculture, 1737 Funako, Atsugi City 243-0034, Japan \\ ${ }^{2}$ Author for correspondence: (k3kondo@nodai.ac.jp) \\ Received April 2, 2013; accepted May 5, 2013
}

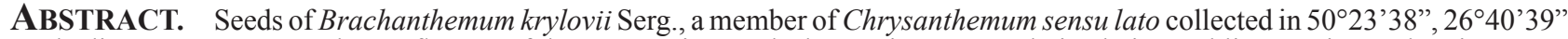
on the limestone area near the confluence of the Katun River and Chuya River, Mts. Altai, Altai Republic, Russian Federation, were sown and germinated to perform seedlings of which root tips were used to observe somatic chromosomes. The karyotype was $\mathrm{K}(2 \mathrm{n}=18)=14 \mathrm{~m}+2 \mathrm{sm}+2 \mathrm{st}$. This diploid katyotype was commonly observed in the members of the Anthemideae or Chrysanthemum sensu lato.
\end{abstract}

KEYWORDS: Brachanthemum krylovii, Chromosomes, Karyotype, Mts. Altai

Brachanthemum is distributed from Altai Republic, Russian Federation to Mongolia, down to Kazakhstan and Gansu Province, the People's Republic of China and forms small, more or less procumbent shrublets, woody at the base (Bremer and Humphries 1993). All of the species of Brachanthemum seem to be quite closely related to each other, except $B$. baranovii is different and placed in the monotypic sect. Dendranthemopsis (Bremer and Humphries 1993). They form woody at base, and their inflorescences are quite closely similar to those of the former Dendranthema (Bremer and Humphries 1993) but the present Chrysanthemum (Trehane 1995).

Brachanthemum krylovii Serg. grows in the limestone area near the confluence of the Katun River and Chuya River, Mts. Altai (50²3’38”, 2640’39”), Altai Republic, Russian Federation (Smirnov 2000). Smirnov (2000) discovered that $B$. baranovii was a natural hybrid between B. krylovii and Chrysanthemum sinuatum (=Dendranthema sinuatum) according to the data of internal transcribed spacer (ITS) and chloroplast DNA. Moreover, Vechernina et al. (2004). has in fact synthesized B. baranovii by artificial cross-pollination between B. krylovii and Chrysanthemum sinuatum and the ovule culture in vitro. The chromosome number of $B$. krylovii was $2 n=18$ (Smirnov 2000 ) while $C$. sinuatum was $2 \mathrm{n}=18$ (Zhmyleva and Kondo 2006). Thus, some introgressive hybridization and gene flow might be occurred between $B$. krylovii and $C$. sinuatum.

Thus, the karyotype of Brachanthemum krylovii is here reported for the first time.

\section{Materials and Methods}

Seeds of Brachanthemum krylovii Serg. were collected near the confluence of the Katun River Chuya River, Mt. Altai (50²3'38', 2640'39'), Altai Republic, Russian Federation. They were sown in wet vermiculite in pots for germination. As soon as they got germination, they were harvested and placed in $0.002 \mathrm{M} 8$-hydroxyqunoline at $18^{\circ} \mathrm{C}$ for $2 \mathrm{~h}$. Then, they were fixed in the mixture of absolute ethanol and glacial acetic acid of $3: 1$. They were macerated in the 2:1 mixture of $1 \mathrm{~N}$ hydrochloric acid and $45 \%$ acetic acid at $60^{\circ} \mathrm{C}$ for $10 \mathrm{sec}$, and then, stained in aceto-orcein for $30 \mathrm{~min}$ before squashed.

The karyotype description followed Levan et al. (1964): $\mathrm{m}=$ median-centromeric chromosome (Arm ratio 1.0-1.7), $\mathrm{sm}=$ submedian-centromeric chromosome (Arm ratio 1.83.0) and $\mathrm{st}=$ subterminal-centromeric chromosome (Arm ratio 7.1 and more).

\section{Results ANd Discussion}

The karyotype of Brachanthemum krylovii Serg. at metaphase was $2 \mathrm{n}=18=14 \mathrm{~m}+2 \mathrm{sm}+2 \mathrm{st}$ described here for the first time (Fig. 2). The largest chromosome at metaphase was $7.66 \mu \mathrm{m}$ while the smallest chromosome was $3.72 \mu \mathrm{m}$. The karyomorphology of the resting chromosomes was the complex chromocenter type and that of the prophase chromosomes was the interstitial type.

The karyotype of Chrysanthemum (previously Dendranthema) sinuatum was described as $2 \mathrm{n}=18=14 \mathrm{~m}+$ $2 \mathrm{sm}+2 \mathrm{st}$ (Zhmyleva and Kondo 2006). The chromosome number of Brachanthemum krylovii was previously described as $2 \mathrm{n}=18$ (Smirnov 2000). Brachanthemum baranovii was synthesized by intergeneric hybridization within all the diploid background in laboratory between Brachanthemum krylovii and Chrysanthemum sinuatum by Vechernina et al. (2004). Thus, the karyotypes of the diploid species of Chrysanthemum sensu lato studied seemed to be quite similar to each other (Kondo et al. 1995; Kondo et al. 2003; Kondo et al. 2012).

Close relationship of Brachanthemum krylovii, B. baranovii and Chrysanthemum sinuatum, all grown in Mts. Altai have been analyzed by using ITS and chloroplast DNA of molecular genetics by Smirnov (2000). Thus, it 
would make sense if those three taxa of Chrysanthemum sensu lato studied here could be all diploid $(2 n=18)$. These chromosome data and relationship within three taxa can be made the sense of the relationship proposed by Smirnov (2000). Further chromosome studies within the three taxa such as Brachanthemum krylovii, B. baranovii and Chrysanthemum sinuatum would be very much necessary to clarify their interspecific relationships.

\section{Literature Cited}

Bremer, K. and Humphries, C. J. 1993. Generic monograph of the Asteraceae-Anthemideae. Bull. Nat. Hist. Museum London (Bot.) 23(2): 71-177.

Contandripoulos, J. 1962. Recherches sur la flore endemique de la Corse et sur ses origins. Ann. Faculte Sci. Marseille 32: 1-354.

Kondo, K., Abd El-Twab, M. H., Idesawa, R., Kimura, S. and Tanaka, R. 2003. Genome phylogenetics in Chrysanthemum sensu lato., Chapter 6. p. 117-200. In: A. K. Sharma and A. Sharma Eds., Plant genome. Biodiversity and evolution. Science Publ., Inc., Plymouth, U. K., pp. 386.

Kondo, K., Smirnov, S. V., Kucev, M. and Shmakov, A. 2012. Somatic chromosomes of Chrysanthemum pulchrum (Ledeb.) Ling. Chrom. Bot. 7: 43-45.

Kondo, K., Tanaka, R., Hong, D., Hizume, M., Yang, Q. and
Nakata, M. 1995. Cytogenetic studies on wild Chrysanthemum sensu lato in China. V. A chromosome study of three species of Ajania, Cancrinia maximowiczii and Dendranthema lavandulifolium in the Chrysantheminae, the Anthemideae, the Compositae in Chinese highlands. Journ. Jpn. Bot. 70: 85-94.

Levan, A., Fredga, K. and Sandberg, A. A. 1964. Nomenclature for centromeric position on chromosomes. Hereditas 52: 201-220.

Mulligan, G. A. 1968. Diploid and tetraploid chromosome races of Chrysanthemum leucanthemum L. s.l. Naturaliste Canad. 95: 793-795.

Smirnov, S. V. 2000. About a hybrid origin Brachanthemum baranovii (Krasch. et Poljak.) Krasch. (Asteraceae) // Art. VII Young. Conf. Bot. In St.-Petersburg (May 15-19, 2000). - SPb.: Buslaj, 2000. - p. 38.

Trehane, P. 1995. (1172) Proposal to conserve Chrysanthemum L. with a conserved type (Compositae). Taxon 44: 439444.

Vechernina N. A., Solovjeva V. V., Tavarkiladze O. K. and Shmakov A. I. 2004. The methodical instructions on regeneration, duplication in vitro and introduction endemics of Altai flora: Brachanthemum baranovii and Dendranthema sinuatum. - Barnaul. - p. 38.

Zhmyleva, A. P. and Kondo, K. 2006. Comparison of somatic chromosomes in some species of Chrysanthemum sensu lato in Russia. Chrom. Bot. 1: 13-22.

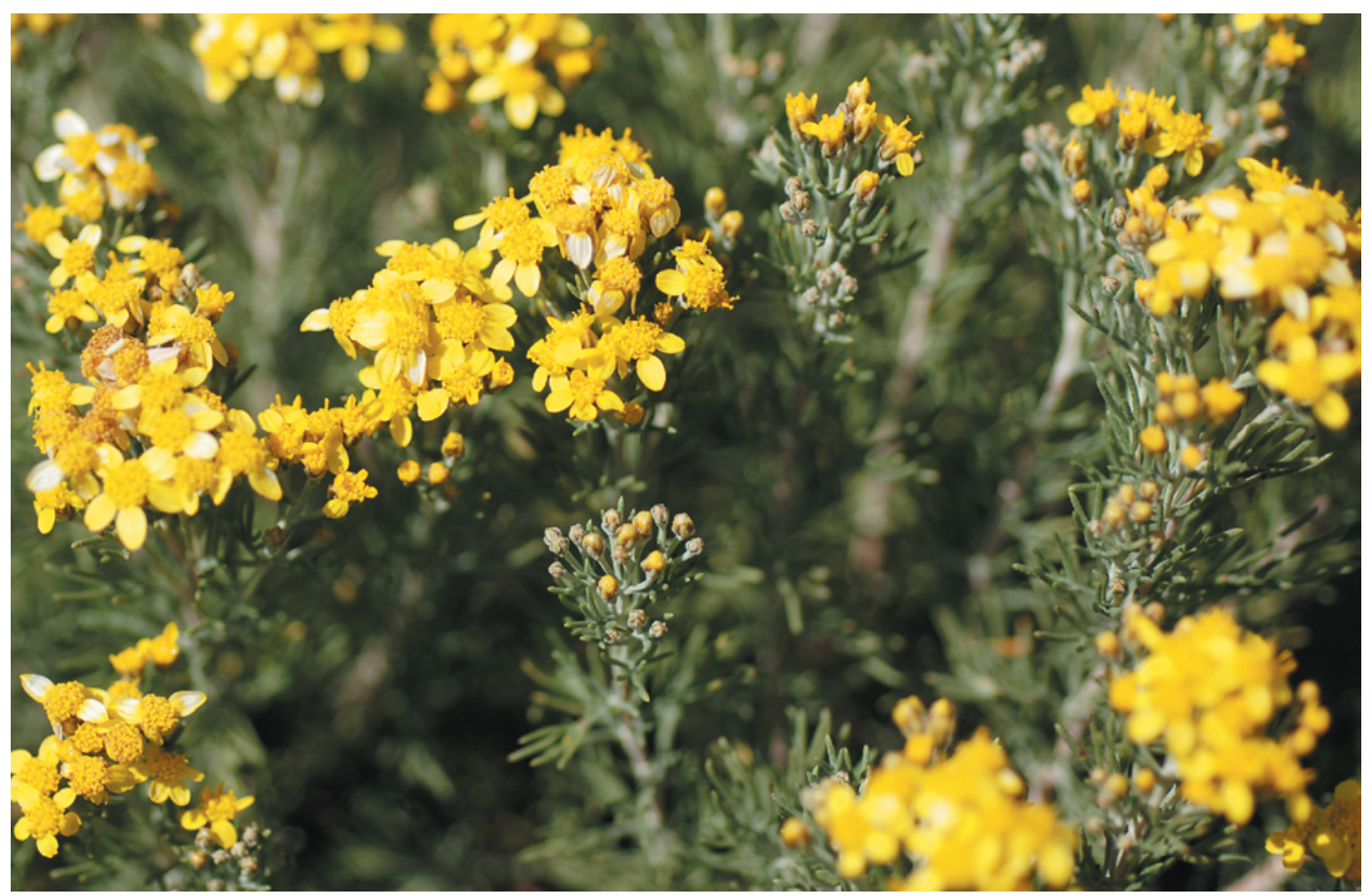

Fig. 1. Brachanthemum krylovii Serg. The research site near the confluence of the Katun River and Chuya River, Mt. Altai (50²3'38”, 2640’39”) .

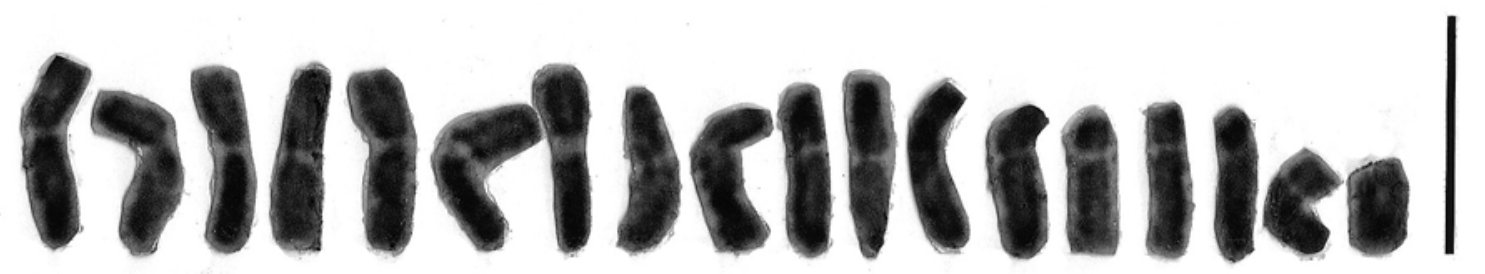

Fig. 2. The karyotype of $2 n=18=14 m+2 s m+2 s t$ in Brachanthemum krylovii Serg. Bar $=10 \mu m$. 